and methodical journal. No. 31, Moskva, 175 p., pp. 14-17. [in Russian].

5. Pometun, O. \& Pyrozhenko, L. (2002). Interaktyvni tekhnolohiyi navchannya: teoriya $i$ praktyka [Interactive teaching technologies: theory and practice]. Kyiv, 136 p. [in Ukrainian].

6. Sukhorukova, H. (2012). Interaktyvna vzayemodiya subyektiv navchalno-piznavalnoyi diyalnosti v pedahohichnomu protsesi [Interaction of subjects of cognitive activity in educational process]. Methods of teaching Computer Science and ICT. No. 4, pp. 27-31. [in Ukrainian]

7. DIALOGUE BOX (2015). Pidkhody ta praktyky z molodizhnykh proektiv dlya porozuminnya ta dialohu [Approaches and practices of youth projects for understanding and dialogue]. Collection of materials and methods. Other education, $83 \mathrm{p}$. [in Ukrainian].

Стаття надійшла до редакції 06.02.2019

УДК 376.64(091)(438)

DOI:

Ореста Карпенко, доктор педагогічних наук, доцент кафедри соціальної педагогіки та корекиійної освіти Дрогобиџького державного педагогічного університету імені Івана Франка

\title{
ПЕРЕДУМОВИ СТАНОВЛЕННЯ ФОРМ ОПІКИ НАД ДІТЬМИ ПОЛЬЩІ (історико-педагогічний аспект)
}

У статі розкрито еволюцію форм опіки над дитиною у Польщі. Благодійність була однією з перших форм опіки. Опіка здійснювалася в основному через костел або релігійні інституиії. Система опіки в Польщзі розвивалася швидко, а інституції, які надавали допомогу дітям, було щораз більше. Громадсько-педагогічній інічіативі у царині опіки над дітьми-сиротами призвели до утворення благодійних товариств, які у складних соиіально-економічних умовах створювали опікунські установи, дбали про задоволення потреб дітей. 3міст опікунсько-виховної діяльності, їі аксіологічні домінанти змінювалися під впливом суспільних явищ, ступеня цивілізаційного розвитку.

Ключові слова: опіка; виховання; благодійні товариства; будинки сиріт; притулки; виховний дім; Польща.

Jim. 15.

Oresta Karpenko, Doctor of Sciences (Pedagogy), Assosiate Profesor of the Social Pedagogy and Special Education Department,

Drohobych Ivan Franko State Pedagogical University

\section{PREREQUISITES OF THE FORMATION OF FORMS OF CUSTODY OF CHILDREN IN POLAND (historical and pedagogical aspect)}

The article reveals the evolution of forms child's custody in Poland. Charity was one of the first forms of custody. Custody was carried out mainly through a church or religious institution. From the XIII century asylum began to arise, the purpose of which was to provide the basic needs: physical security, religious and moral education, and sometimes teaching reading, writing and mathematics. The emergence of orphanhood and homeless children was generated by war, poverty or the epidemic. Therefore, it was important to create shelters, orphanages, as well as other cells in which children would receive support and assistance.

In churches and religious communities, the trusteeship and educational function was performed by hospitals and shelters, which, on the basis of Christian charity, provided support and assistance to the needy and abandoned children. Over time, the placement of natural and social orphans in foster families was less associated with the activities of charitable institutions. In 1775, a central body for the management of public charity was established, entitled "Commission on Hospitals".

The system of care in Poland developed rapidly, and the institutions that provided assistance to children were ever more numerous. The community-pedagogical initiative in the field of orphaned children care led to the formation of charitable societies, which, in difficult socio-economic conditions, established trusteeship institutions, took care of the needs of children. Public welfare of children on ethnic lands during the Austro-Hungarian period was partial, not covering all its units. The measures of the Austro-Hungarian state, aimed at providing elementary care to orphans, did not meet the expectations of the population and did not bring the desired results.

The content of the guardian-educational activity, its axiological dominant changed under the influence of social phenomena, the degree of civilization development. The organization of guardianship was conditioned by threatening social phenomena, the struggle for survival, wars that exacerbated the problems of orphanhood, poverty 
and begging. This is primarily about the dependence of the state's functions of guardianship, in particular, on their reduction, and the increase of the threat of social orphanhood among children.

Keywords: care; education; charitable societies; orphanages; shelters; educational home; Poland.

П остановка проблеми. Право дитини на опіку і виховання в сім'ї зафіксоване у міжнародних документах (Конвенція ООН про права дитини, Декларація прав дитини, Всесвітня декларація про забезпечення виживання, захисту і розвитку дітей тощо), у законодавчих актах кожної держави. Обов'язки батьків щодо виховання та розвитку дитини, забезпечення іï прав на належне батьківське виховання, права батьків по захисту дитини, розв'язання ними питань, що стосуються виховання дитини, урахування її думки при

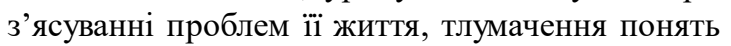
“усиновлення”, “опіки”, створення прийомної сім'ї, дитячого будинку сімейного типу та низка інших питань відображені у законодавчих документах. Особливо гостро питання соціальної опіки дітей $\mathrm{i}$ молоді постає у перехідні етапи суспільнополітичного й соціально-економічного розвитку Польщі.

Аналіз останніх досліджень і публікацій. В останні десятиліття зацікавлення до проблем опіки над дітьми у педагогічній теорії практиці Польщі зростає. Опікунська діяльність окремих інституцій в окремі історичні періоди Польщі частково висвітлена. Опікунсько-виховна діяльність благодійних товариств Польщі досліджує Х. Дзюбинська [1], виховання дітейсиріт у міжвоєнний період у Польщі - Ю. Яким [5], будинок сиріт як інституційна форма опіки i виховання дітей - М. Чепіль [4]; опіка і виховання дітей дошкільного віку - Б. Мажец [3]. Більш повного висвітлення потребують витоки ідей опіки, громадського-педагогічні ініціативи у сфері опіки.

Мета статті - розкрити витоки та педагогічні засади становлення форм опіки над дітьми у Польщі.

Виклад основного матеріалу. У польській педагогічній думці заслуговують на увагу міркування 3. Домбровського: еволюційний розвиток людини дає можливість висунути припущення, що наші предки, живучи в складних умовах, піклувалися один про одного. Виявом опіки, наприклад, був порядок поділу здобутої під час полювання їжі. Автор сформулював кілька гіпотез, які торкаються опіки між людьми. Першою 3 них $\epsilon$ твердження, що a) передісторична опіка полягала в тому, що родичі дбали про дітей до часу їх відокремлення (самостійності); б) опікунська діяльність в окремих сферах розвинулася раніше, ніж у звірів, в) межі задоволення потреб були наближені до тих, які сьогодні спостерігаємо у найбільш розвинутих звірів (мавп) - це біологічні потреби, безпека, приналежності, забави і яскраве зародження вищих потреб, г) механізми інстинкту i особистого досвіду опіки значною мірою підтримані або замінені здобутими опікунськими діями, д) основні функції опіки - збереження життя і забезпечення певного процесу розвитку - не відрізнялися суттєво від функцій опіки звірів, е) опіка між людьми мала охороняти підопічних від небезпеки, пов'язаної з місцем проживання тощо $[9,37]$.

3 найдавніших часів суспільство намагалося протидіяти сирітству, керуючись релігійними та гуманістичними мотивами. Тогочасною домінуючою формою опіки була благодійність. Опіка здійснювалася в основному через костел або релігійні інституції. Костел стверджував, що найважливішою є допомога, якої потребує людина через ближнього. Бідні особи могли розраховувати на підтримку рідних і чужих людей. Кожен мав обов'язок поділитися свої добром з тими, хто його потребус. 3 XIII ст. почали виникати притулки, метою яких було забезпечення основних потреб: фізична безпека, релігійне і моральне виховання, а інколи навчання читанню, письму і математиці $[2,158]$. Поява сирітства і бездомних дітей була породжена війною, бідністю або епідемією. Тому важливо було створювати притулки, дитячі будинки, а також інші осередки, в яких діти отримували б підтримку і допомогу.

В епоху середньовіччя допомогу отримували не тільки сироти, бідні, але й хворі люди, жебраки, прочани. Поводження з дітьми 3 бідних родин було жорстоким. Дітей віком до 12 років змушували тяжко працювати, а часто понад силу. Лікарні виконували роль опікунської інституції. У Х ст. почали виникати медичні братства, метою яких була благодійна діяльність. У ХІІ ст. краківський єпископ Іво Одровонж упровадив у Польщі закон Святого Духа, заснований у 1198 р., який уже в XVI ст. мав під опікою 1200 лікарень [14, 59]. У Польщі 1108 року Петро Властв заснував на горі Суботці лікарню і віддав під опіку ченцям Св. Августина. Це - найстаріша лікарня в Польщі, яка існувала до XVIII ст. Невдовзі після цього 1170 року Мєшко Старий спорудив лікарню у м. Познань, а опіку над ними мали медичні братчики закону Св. Яна Єрозолімского [10, 25]. Деякі тогочасні лікарні неохоче опікувалися сиротами. Діти, залишені мамами в лікарнях, 
потрапляли на виховання усела, а потім їх навчали відповідної до статі професії. У кінці середньовіччя система допомоги була добре розбудована. Опіку, допомогу і підтримку можна було отримати в різних інституціях. Занедбаними дітьми і сиротами займалися лікарні для дорослих, заклади опіки при парафіях.

В історії педагогічної думки Польщі опіка у прийомній сім'ї має давню традицію, однак як інституційна форма опіки сформувалася тільки під кінець XVI ст. Значні досягнення у розвитку опіки над осиротілими дітьми, особливо покинутими немовлятами, характерні для Польщі XVII ст. Вагомий внесок уіїі розбудову зробив французький св. Вікентій де Поль (фр. Vincent de Paul, 15811660). 3 метою зменшення смертності дітей, що перебували у притулках для убогих, він роздав їх під опіку жінок у селах, чим досягнув позитивних результатів. У 1717 р. св. Г. Бодуен спорудив сиротинець для підкинутих дітей. У 1736 р. у Варшаві з метою прийому і виховання немовлят французький місіонер Г. Бодуен заснував клініку - виховний дім. 3 часом цю ініціативу підтримала держава і костел. Його вважали засновником моделі прийомної сім’ї $[11,17]$.

При костелах і релігійних громадах опікунськовиховну функцію виконували лікарні і притулки, які на засадах християнського милосердя надавали підтримку і допомогу нужденним і покинутим дітям. 3 плином часу розміщення природних i соціальних сиріт уприйомних сім'ях було щоразу менше пов'язане із діяльністю благодійних інституцій. У 1775 р. засновано центральний орган для управління громадською доброчинністю під назвою "Комісія над лікарнями".

Система опіки в Польщі розвивалася швидко, а інституцій, які надавали допомогу дітям, було щораз більше. Опікою над дітьми займалися інституцій при костелах. Так, орден єзуїтів (1564) виконував важливу освітню місію - організовував навчання учнів і піклувався про умови їхнього розвитку. Єзуїти намагалися заангажувати найбагатшу молодь, відкривши при своїх колегіумах високого рівня бурси, поряд з якими були і бурси для бідної молоді. Обов'язкова участь у хорах була платою за безкоштовне утримання.

Більш результативною діяльністю в опіці над дітьми відзначився орден піарів (1657), система якого базувалася на відкритті коледжів і шкілінтернатів. Останні мали забезпечити молоді не тільки дах над головою, але й ознайомити іiї зі світом і суспільством для надання можливості служити власному народові. Реформуванням шкільної системи піарів зайнявся священик С. Конарський. У 1740 р. відкрив у Варшаві шляхетний коледж, який складався 3 двох закладів: школи (навчальні аудиторії) й інтернату (спальні, їдальня, лазня, зал для розваг). Щороку тут навчалися понад 60 вихованців, а за весь період його діяльності (1740 - 1882) - 1229 осіб. Велику увагу приділяли моральному (почуття честі й пошани до власної гідності, правдолюбства, сили волі, поваги до старших) і релігійному вихованню (молитва), а також правилам етикету [15].

Система опіки в Польщі розвивалася швидко, а інституцій, які надавали допомогу дітям, було щораз більше. Громадсько-педагогічній ініціативі у царині опіки над дітьми-сиротами на початку XIX ст. призвели до утворення благодійних товариств, які у складних соціально-економічних умовах створювали опікунські установи, дбали про задоволення потреб дітей. Це, насамперед, Віленське (1807 - 1830), Варшавське (1814 1914), Люблінське (1815 - 1952), Каліське (1825 - 1851, 1880 - 1914), Радомське (1874 - 1914, 1923 - 1930) благодійні товариства, діяльність яких у різні роки проходила з різною інтенсивністю. Їхній внесок в організацію закладів опіки, налагодження соціального виховання, подолання дитячої безпритульності, забезпечення елементарної $\mathrm{i}$ професійної освіти є значущим.

Опікою над дітьми займалися інституції при костелах. Так, орден єзуїтів (1564) виконував важливу освітню місію - організовував навчання учнів і піклувався про умови їхнього розвитку. Єзуїти намагалися заангажувати найбагатшу молодь, відкривши при своїх колегіумах високого рівня бурси, поряд з якими були і бурси для бідної молоді. Обов'язкова участь у хорах була платою за безкоштовне утримання.

У 1835 р. створена Головна опікунська рада, яка займалася питаннями відкриття невеликих дитячих осередків. Ї̈і діяльність, як стверджує 3. Домбровський, досягла успіху під час Першої світової війни, коли гостро постала потреба подолання проблем сирітства, бідності, жебрацтва $[8,34]$.

У другій половині XIX ст. у європейських країнах під впливом робітничого руху організовувалися публічно-правничі системи опіки над дитиною. Польща не мала можливості розвитку соціальної політики щодо молодого покоління, а розвиток опікунської діяльності розпочався тільки після Першої світової війни. Період II Речі Посполитої був, властиво, початком і спробою творення системи опіки над дитиною, започаткування благодійно-доброчинної опіки.

У розвитку опіки над дітьми важливу роль відіграли закони австрійського парламенту та 
урядові розпорядження. Питання опіки різних категорій населення Австро-Угорщини зініційовані конституційними змінами (1867), які дали можливість усім громадянам, що проживають на території держави, створювати благодійні товариства, культурно-освітні товариства тощо, які й займалися опікою дітей і молоді. Держава безпосередньо не займалася справами опіки. Розпорядження Міністерства справедливості, громадських справ і фінансів "Про нагляд та контроль за діяльністю опікунських закладів і використання коштів для їх потреб” увійшло в дію з 1 січня 1868 р. [13, 140]. Суспільна опіка дітей на етнічних землях у період Австро-Угорщини носили частковий характер, не охоплювала усіх піi ланок. Заходи австро-угорської держави, спрямовані на забезпечення елементарної опіки сиротам, не виправдали очікувань населення і не принесли бажаних результатів.

У 1892 р. $з$ ініціативи Б. Маркевича відкрито притулок для сиріт у Пясткові. Після кількох років діяльності керівники Селезіянського Згромадження у Турині почали обмежувати чисельність вихованців і ускладнювати виховну роботу. Б. Маркевич звільнився за власним бажанням і створив світське товариство “Стриманість і робота", статут якого базувався на порадах св. Івана Боско. Про успішну діяльність товариства свідчить той факт, що у 1902 р. заклад налічував більше 250 занедбаних і знедолених вихованців. Через 10 років діяльності притулку декілька його вихованців навчалися у польських і закордонних університетах. Крім того, вихованці Б. Маркевича відкрили опікунські заклади у Варшаві, Вільно, дві установи у Галичині. Упродовж 1892 - 1912 рр. отримали професію близько 1500 дітей, які популяризували ідеї Б. Маркевича у Польщі, Свропі і Північній Америці $[12,79]$.

На зламі століть дослідники проблему сирітсва розглядають у контексті суспільної ситуації у Польщі. Йдеться насамперед про залежність виконання опікунських функцій державою, зокрема, їх зменшення, і збільшення загрози виникнення соціального сирітства серед дітей $[6,23]$. Перші спроби опіки над дітьми започатковано ще на початку XX ст., коли виникли сиротинські гнізда, костюшківські села.

Висновки. У досліджуваний період організаційні форми опіки еволюціонували. Зміст опікунсько-виховної діяльності, іiї аксіологічні домінанти змінювалися під впливом суспільних явищ, ступеня цивілізаційного розвитку. Організація опікунської діяльності зумовлювалася загрозливими суспільними явищами, боротьбою за виживання, війнами, які поглиблювали проблеми сирітства, бідності і жебрацтва. Йдеться насамперед про залежність виконання опікунських функцій державою, зокрема, їх зменшення, і збільшення загрози виникнення соціального сирітства серед дітей. Подальших наукових розвідок потребує становлення інституційних форм опіки у країнах $€ C$.

\section{ЛІТЕРАТУРА}

1. Дзюбинська X. Становлення благодійних товариств у Польщі. Педагогічна теорія і практика в контексті інтеграційних процесів : матеріали Міжнарод. наук.-практ. конф., 25 - 26 квітня 2014 р. Тернопіль, 2014. С. 270 - 276.

2. Карпенко О. С. Теоретико-методичні засади опіки над дітьми у педагогічному доробку Ю.-Ч. Бабіцького. Наукові записки Вінницького державного педагогічного університету імені Михайла Коиюбинського. Серія: Педагогіка $і$ психологія. Вінниця, 2016. Вип. 45. С. 129-133.

3. Мажец Б. Przedszkola niepubliczne a kształtowanie sieci przedszkoli w Polsce. Людинознавчі студії. Серія “Педагогіка”. Дрогобич, 2018. Вип. 7/39. С. 172-184.

4. Чепіль М., Яким Ю. Будинок сиріт як осередок творення виховної системи у Польщі (1918 - 1939 рр.). Науковий вісник Південноукраӥнського національного педагогічного університету ім. К. Д. Уиинського. Вип. 1 - 2. Одеса : НППУ ім. К. Д. Ушинського, 2012. С. 141 - 149.

5. Яким Ю. Становлення інституційних форм виховання дітей-сиріт у Польщі (1918 - 1939 рр.). Гуманізація навчально-виховного процессу. Вип. LIII. Ч. II. / За заг. ред. В. І. Сипченка. Слов'янськ : СДПУ, 2010. С. 164 - 175.

6. Badora S., Badora K.P. Społeczne uwarunkowania niedostatków opieki. System opieki kompensacyjnej $w$ zjednoczonej Europie/Red. S. Badora, D. Marzec. Kraków : Impuls, 2002. S. 23 - 54.

7. Bartnicka K., Szybiak I. Zarys historii wychowania. Warszawa: "Żak", 2001.220 s.

8. Dąbrowski Z., Kulpiński F. Pedagogika opiekuńcza: historia, teoria, terminologia. Olsztyn : Wyd. Uniwersytetu Warmińsko-Mazurskiego, 2002. $207 \mathrm{~s}$

9. Dąbrowski Z. Pedagogika opiekuńcza w zarysie. 1. Olsztyn : Wyd. Uniwersytetu WarmińskoMazurskiego, 2006. 269 s.

10. Kęmpski Cz. Idea miłosierdzia a dobroczynność i opieka. Lublin : Wyd. UMCS, 2003. $145 \mathrm{~s}$.

11. Koralewski, K. (1918). Opieka Społeczna: (dobroczynność publiczna). Warszawa: Nakł. Księgarni F. Hoesicka, 1918. 206 s.

12. Meissner-Łozińska J. Markiewicz Bronisław. 
Encyklopedia Pedagogiczna XXI wieku. T. III. MO. Warszawa : Żak, 2004. - S. 79 - 80.

13. Przekłady z Dziennika praw Państwa dla Królewstwa Galicji i Wielkiego Księstwa Krakowskiego. Lwów, 1867. S. 140.

14. Rudak E. Pomoc dzieciom w czasie wojny: sympozium. Warszawa : Fundacja "Moje Wojenne Dzieciństwo", 2002. 106 s.

15. Surdacki M. Losy dzieci porzuconych w społeczeństwie europejskim do XX wieku. Dziecko $w$ rodzinie i spoleczeństwie / red. K. Jakubiak, W. Jamrożek. Bydgoszcz, 2002. S. 141-165.

\section{REFERENCES}

1. Dziubynska, Kh. (2014). Stanovlennia blahodiinykh tovarystv $\mathrm{u}$ Polshchi [The formation of charitable societies in Poland]. Pedahohichna teoriia i praktyka $v$ konteksti intehratsiinykh protsesiv: materialy Mizhnarod. nauk.-prakt. konf. - Pedagogical theory and practice in the context of integration processes: Proceedings of International Scientific Practical Conference, April, 25 - 26. (pp.270-276). Ternopil. [in Ukrainian].

2. Karpenko, O. (2016). Teoretyko-metodychni zasady opiky nad ditmy u pedahohichnomu dorobku Yu.-Ch. Babitskoho [Theoretical and methodical principles of child custody in pedagogical work Yu.Ch. Babitsky]. Scientific notes of the Vinnitsa Mikhail Kotsiubynsky State Pedagogical University. Series: Pedagogy and Psychology, Vol. 45, pp. 129-133. [in Ukrainian].

3. Mazhets, B. (2018). Przedszkola niepubliczne a kształtowanie sieci przedszkoli w Polsce [Orphanage as a center for the formation of the educational system in Poland (1918 - 1939)]. Human Studies. Series of "Pedagogy", Vol. 7/39, pp. 172184. [in Ukrainian].

4. Chepil, M., \& Yakym, Yu. (2012). Budynok syrit yak oseredok tvorennia vykhovnoi systemy u Polshchi (1918 - 1939 rr.) [Orphanage as a center for the formation of the educational system in Poland (1918 - 1939)]. Scientific Herald of the Southern K. D. Ushinsky Ukrainian National Pedagogical University, Vol. 1 - 2, pp. 141 - 149. [in Ukrainian].

5. Yakym, Yu. (2010). Stanovlennia instytutsiinykh form vykhovannia ditei-syrit u Polshchi (1918 - 1939 rr.) [Formation of institutional forms of education of orphan children in Poland (1918 - 1939)]. Humanization of the educational process, Vol. LIII, part. II, pp. $164-175$. [in Ukrainian].

6. Badora, S., \& Badora, K. (2002). Społeczne uwarunkowania niedostatków opieki [Social determinants of care deficiencies]. Compensation care system in a united Europe. (Eds.). S. Badora, D. Marzec. Krakow: Impuls, pp. 23-54.[in Polish].

7. Bartnicka, K., \& Szybiak, I. (2001). Zarys historii wychowania [Outline of the history of education]. Warsaw: Żak, 220 p. [in Polish].

8. Dąbrowski, Z., \& Kulpiński, F. (2002). Pedagogika opiekuńcza: historia, teoria, terminologia [Caring pedagogy: history, theory, terminology]. Olsztyn: Publ. Uniwersytetu Warmińsko-Mazurskiego, 207 p. [in Polish].

9. Dąbrowski, Z. (2006). Pedagogika opiekuńcza $w$ zarysie 1 [Custody pedagogy in outline 1]. Olsztyn: University of Warmia and Mazury, 269 p. [in Polish].

10. Kęmpski, Cz. (2003). Idea miłosierdzia a dobroczynność $i$ opieka [Idea of mercy and charity and care]. Lublin: UMCS Publ., 145 p. [in Polish].

11. Koralewski, K. (1918). Opieka Społeczna: (dobroczynność publiczna) [Social custody: (public charity)]. Warsaw: Nakł. Bookstore F. Hoesicka, 206 p. [in Polish].

12. Meissner-Łozińska, J. \& Markiewicz Bronisław (2004). Encyklopedia Pedagogiczna XXI wieku [Educational Encyclopedia of XXI century]. Vol. III, M-O. Warsaw: Żak, pp. 79-80. [in Polish].

13. Przekłady z Dziennika praw Państwa dla Królewstwa Galicji i Wielkiego Księstwa Krakowskiego (1867). [Translations from the Journal of State Rights for the Kingdom of Galicia and the Grand Duchy of Krakow]. Lviv, p. 140. [in Polish].

14. Rudak, E. (2002). Pomoc dzieciom w czasie wojny: sympozium [Help for children during the war: symposium]. Warsaw: Foundation "My War Childhood", 106 p. [in Polish].

15. Surdacki, M. (2002). Losy dzieci porzuconych w społeczeństwie europejskim do XX wieku [The fate of children abandoned in European society up to the XX century]. A child in the family and society.(Eds.). K. Jakubiak, W. Jamrożek. Bydgoszcz, pp. 141-165. [in Polish].

Стаття надійшла до редакції 14.02.2019

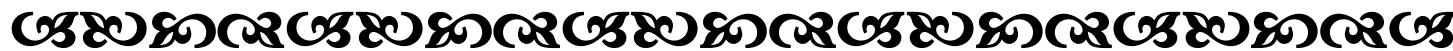

"Кожне слово вихователя повинно нести в собі добро, справедливість, қрасу - и иьму суть наших повчань”. 